胸部単純X線写真が診断に有用であった右主気管支断裂損傷の 1 例

西海 昇, 藤森 賢, 濱本 篤, 米谷 文雄, 加賀基知三, 岩崎 正之, 井上 宏司

要旨

気管・気管支断裂損傷は，鈍的胸部外傷の中で頻度は少ないが，致命率は高い．われわれは，受傷初期の胸部単純X 線写真が診断に有用であった，18歳男性のバイク外傷による右主気管支断裂損傷（日本外傷学会，気管，気管支損傷 分類 Ib）の 1 例を経験した. 胸部単純X線写真上，tracheobronchial stripe の描出，進行性の䋛走する気管と右主気 管支周囲の透亮像，continuous diaphragm sign，右側の Naclerio's V-sign を認め，これらは縦隔気腫を示唆する所 見であったささらに，奇静脈近傍の右主気管支陰影は不鮮明化し，その外側に血腫像を認めた．以上の所見から右主 気管支断裂損傷が示唆された。手術は損傷部位を直接縫合閉鎖し，救命した。

索引用語：鈍的胸部外傷，気管気管支損傷，縦隔気腫，片肺換気チューブ

blunt chest trauma, tracheobronchial injury, mediastinal emphysema, Univent

\section{はじめに}

気管・気管支断裂損傷 (tracheobronchial disruption injury, TBDI） は，鈍的胸部外傷の中で頻度は少ない が, 致命率は15-30\%に達する重篤な外傷である ${ }^{1-3)}$.今 回われわれは, 受傷初期の胸部単純 $\mathrm{X}$ 線写真が診断に 有用であった右主気管支断裂損傷の 1 例を経験した。

\section{症例}

症 例 : 18歳, 男性.

主 訴: 交通外傷後進行性の頸部と胸部の皮下気腫.

経 過：1997年 2 月 1 日バイク走行中，乗用車と接 触し転倒, 前胸部を強打した。他院搬送時, 頸部と前 胸部に皮下気腫を認めた。皮下気腫が増強し，受傷 40 分後に，当院救命救急センターに転送された。

来院時現症 : 意識清明. 呼吸数 36 回/分, 血圧 $162 / 82$ $\mathrm{mmHg}$, 脈拍数 $100 /$ 分. 軽度の呼吸困難と, 少量の血 痰を認めた。顔面・頸部・胸部・臍部に皮下気腫を認 めた．右胸腔ドレーン挿入後持続性の空気漏出を認め た。胸部以外の合併損傷は腰椎破裂骨折であった。

東海大学医学部外科学系 呼吸器外科学

原稿受付 2001 年 3 月 5 日

原稿採択 2001 年 10 月15日
来院時の血液ガス分析 : $\mathrm{PaCO}_{2} 37 \mathrm{mmHg}, \mathrm{PaO}_{2} 82$ $\mathrm{mmHg}$ ( $5 l$ 酸素マスク吸入下).

受傷後20分の胸部単純 $X$ 線写真 (Fig. 1A)：右気胸 と肺挫傷に起因する浸潤陰影を右上肺野に認めた。上 縦隔陰影は拡大し，気管外縁と右主気管支外縁の tracheobronchial stripe が描出された。左右の大胸筋下 の皮下気腫を認めた。

受傷後80分の胸部単純 $X$ 線写真 (Fig. 1B)：胸腔ド レーン挿入後の写真. 頸部から大胸筇下の皮下気腫は 増加した。上縦隔陰影はさらに拡大し, 縦走する気管 周囲の透亮像は増加した。 心陰影に重なる continuous diaphragm sign ${ }^{4)}$ ，右横隔膜下の Naclerio's V-sign ${ }^{5}$ は, 緹隔気腫の下縦隔への進行を示した. tracheobronchial stripe は, 右上縦隔から右主気管支まで明瞭に描 出されたが, 奇静脈付近の右肺門で不鮮明となり，そ の外側に低い透過性の陰影を認め，血腫像と考えた。 以上の所見から，右主気管支断裂損傷が疑われた。

受傷後90分の奇静脈レベルの CT (Fig. 2)：右主気 管支末梢から右上幹気管支にかけての腹側に $2 \mathrm{~cm}$ の 血腫像を認め，右主気管支末梢の気管支断裂損傷と診 断した。この血腫の位置は食道と離れており，食道損 傷を否定した。

受傷後120分の気管支鏡所見（Fig. 3)：右上幹分岐 


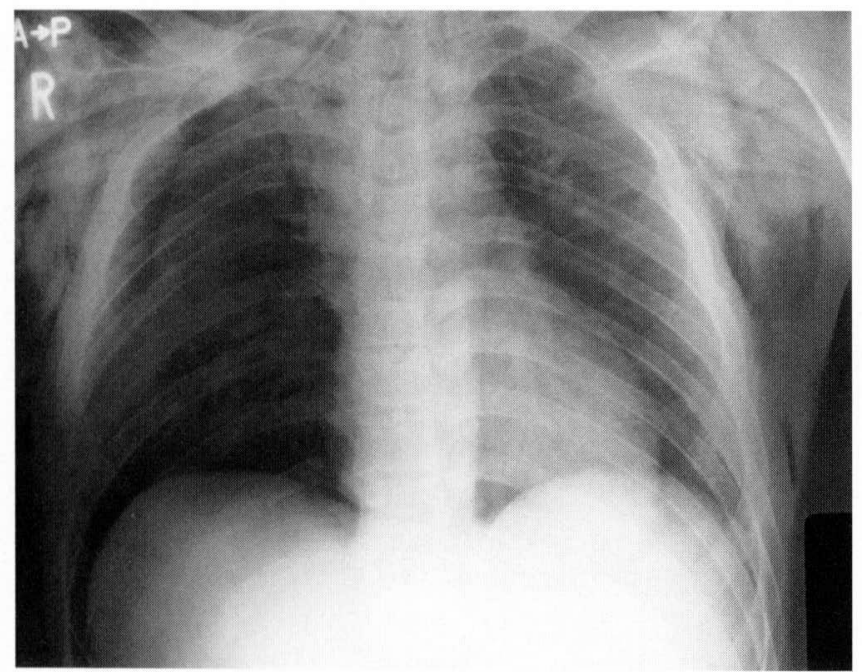

Fig. 1 A : Chest roentgenogram 20 minutes post-injury Mediastinal emphysema shadows around the tra chea and the right pulmonary hilum, subcutaneous emphysema, and right pneumothorax can be seen.

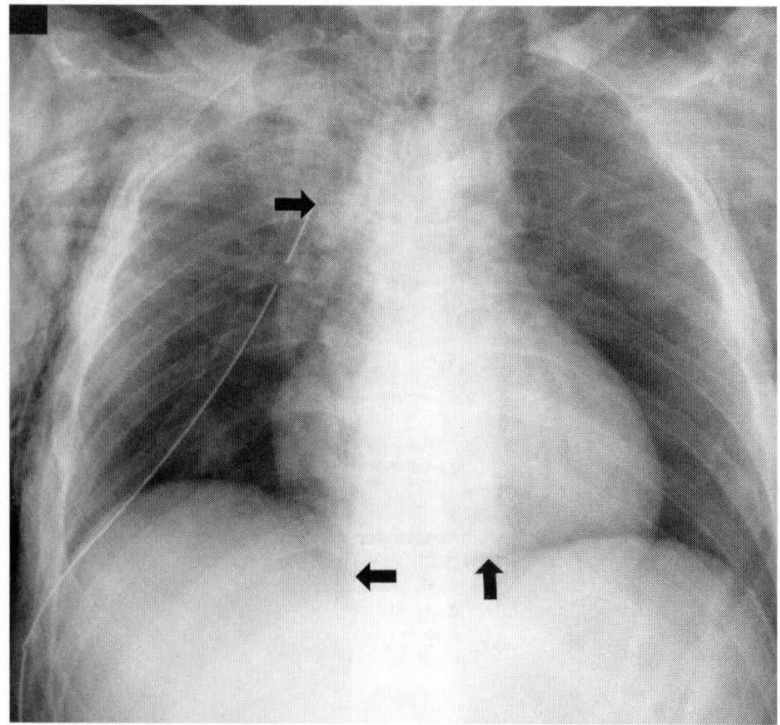

Fig. 1 B : Chest roentgenogram 120 minutes post-injury Progressive mediastinal emphysema shadow and subcutaneous emphysema can be seen, as are the continuous diaphragm sign (upper arrow) and right Naclerio's V-sign (left arrow). In addition, a hematoma shadow is visible around the right main bronchus (right arrow).

直前の右主気管支膜様部から軟骨部右壁にかけ，環状 に気管支粘膜の発赤と腫脹を認めた。気管支鏡診断は， 右主気管支全層裂傷，『日本外傷学会，気管，気管支損 傷分類 Ib $(\mathrm{rMB}) 』{ }^{6)}$ であった.

右主気管支裂傷と診断後は, 麻酔開始まで自発呼吸 を維持した。

手術所見：受傷から 7 時間後に手術室で Univent ${ }^{7)}$

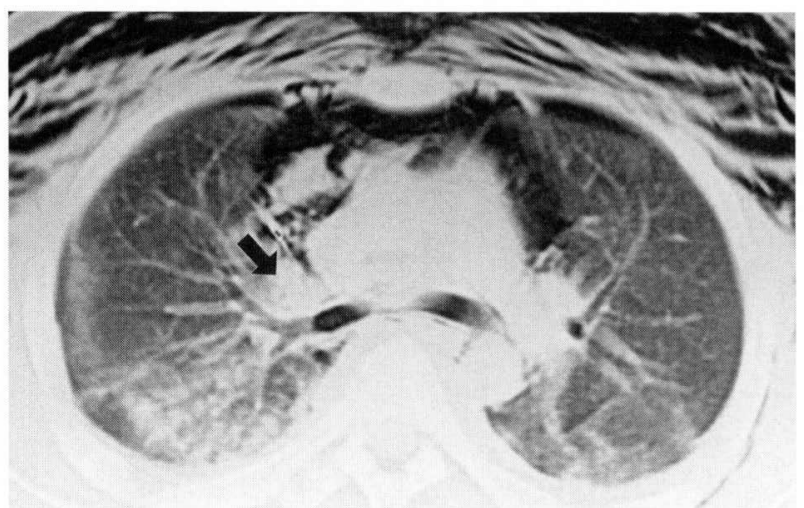

Fig. 2 Thoracic CT at the level of the bifurcation of the right superior bronchial trunk 90 minutes post-injury

A hematoma shadow can be seen before the bifurcation of the right main bronchus and the right superior bronchial trunk (arrow).

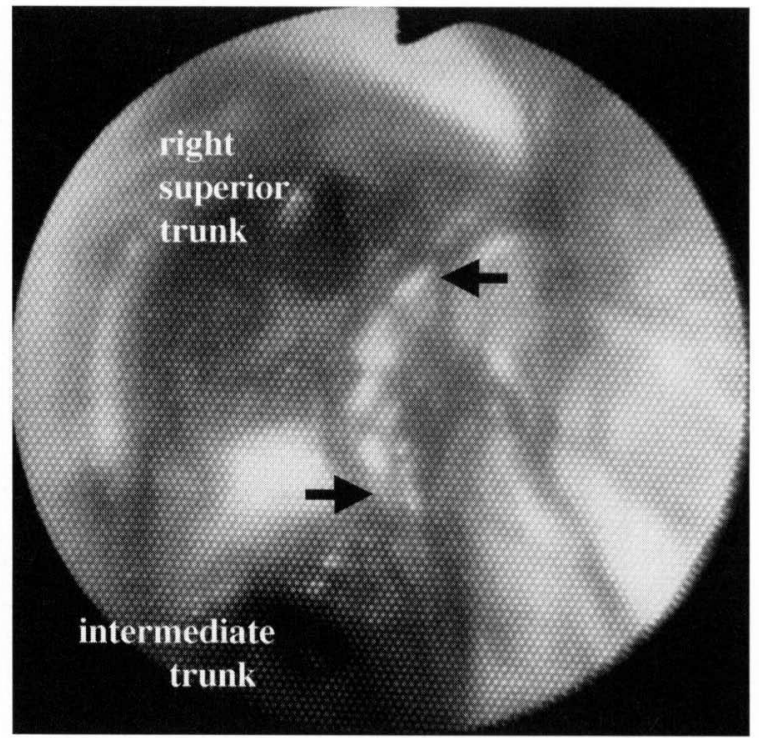

Fig. 3 Bronchoscopic findings 120 minutes post injury

(view is looking down at the entrance of the intermediate bronchial trunk and the right superior trunk from the periphery of the right main bronchus)

An annular disruption injury can be seen extending from the cartilaginous portion of the right wall (left arrow) to the membranous portion (right arrow) of the periphery of the right main bronchus.

を挿管，その可動式ブロッカーで右主気管支を閉塞， 左片肺換気を開始した。胸腔鏡併用の小開胸手術を行 った．奇静脈周囲の縦隔胸膜の内側は，血腫で覆われ 膨隆していた。血腫を除去し, 奇静脈を頭側に牽引す 


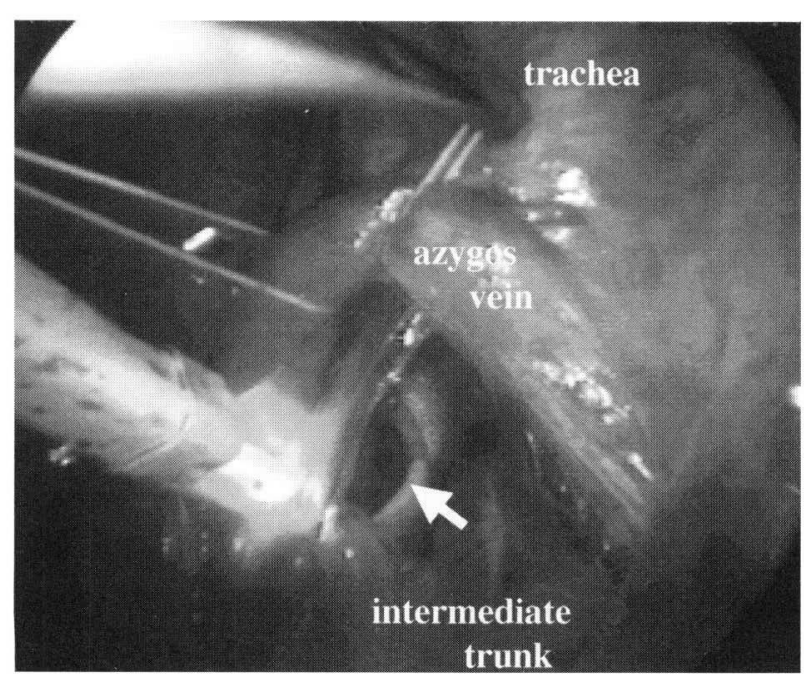

Fig. 4 Site of injury photographed through a thoracoscope

Silk thread was passed through the azygos vein, and craniad traction is being exerted. Annular disruption injury extending from the bronchial cartilaginous portion (arrow) of the right wall of the right main bronchus immediately cephalic to the right superior trunk can be seen.

ると，右上幹分岐直前の右主気管支は，膜様部から軟 骨部右壁にかけ全周の $1 / 3$ 周に及ぶ環状全層裂傷『日 本外傷学会, 気管, 気管支損傷分類 Ib $(r M B, m e m) 』$ であった (Fig. 4)。挫滅した気管支組織を除去し，右 主気管支の単純縫合閉鎖を行った。手術室でUnivent を抜管し，自発呼吸とした。

術後経過：12病日に胸腔ドレーンを抜去した。60病 日に腰椎骨折に対し後方固定術を行い，97病日軽快退 院した。

\section{考察}

気管・気管支断裂損傷（TBDI）は，鈍的胸部外傷の $0.5 \sim 2.8 \%$ と報告され，頻度の少ない病態である ${ }^{1-3,8)}$. 東海大学病院に扔いて，1988年から2000年までの13年 間に入院治療を要した鈍的胸部外傷は678例で, TBDI はそのうちの 9 例 $(1.3 \%)$ を占めた。 Kirsh ら ${ }^{8}$ は， TBDI は医療機関到着前に死亡することが多く，死亡 率は 15 - $30 \%$ に達する重篤な胸部外傷であると述べて いる。われわれは，TBDI を含鈍的胸部外傷の多く は，的確な病態診断と画像診断，ならびに迅速な初期 治療により救命可能であるとの見解を持ってい $3^{7,9-11)}$.

Calhoon ら ${ }^{12)} は$, TBDI の初期診断として (1) 臨床
症状，(2) 胸部単純 X線写真所見，(3) 気管支鏡検査所 見の三つが重要であると報告している。われわれは， この 3 項目について検討した.

\section{1. 臨床症状}

鈍的胸部外傷の中で, 進行性の皮下気腫を認めた時 は，まずTBDI を考える。TBDIでは，血痰は高頻度 でわれわれは 9 例全例に認めた。低酸素血症は，完 全とそれに近い主気管支断裂損傷（2 例）と，広範囲 の肺挫傷を伴った症例（1例）に認めた。

\section{2 . 胸部単純 $\mathbf{X}$ 線写真}

Devitt $ら^{1)}$ は, TBDI の胸部単純写真の特徵は, 気 胸・縦隔気腫・皮下気腫の 3 つであると述べている. われわれは，受傷側の気胸を 9 例中 8 例，皮下気腫を 6 例認めた。

縦隔気腫を示す所見は次の三つである.

1. tracheobronchial stripeの描出とその外側に縦 走する透亮像

2. continuous diaphragm $\operatorname{sign}^{4)}$ : 左右の横隔膜の 線が，心陰影に重なり一本の線に連なって見える

3. Naclerio's V-sign' ${ }^{5)}$ : 縦隔胸膜の折り返しが横 隔膜下で $V$ 字型に見える

鈍的外傷において, 縦隔気腫の鑑別診断は, TBDI の 他に，食道損傷と梨状窩損傷である。これらとの鑑別 は次の所見により可能である.

われわれは Devittらが指摘した三つの所見に加光， 次の二つの所見が重要であると考えた。

1。気管支損傷部に一致した tracheobronchial stripe の途絶や気管支陰影の不鮮明化

2。損傷部周囲の血腫像

われわれは，この二つの所見を 9 例全例で認め,こ れらの所見は, TBDI を示唆すると共に, 気管・気管支 損傷部位の推測に有用であった。

胸部と頸部の CT は，TBDI の血腫の存在部位を確 実に診断し，食道損傷や梨状窩損傷との鑑別を容易と した。胸部単純写真における fallen lung $\operatorname{sign}^{81}$ は，完 全主気管支断裂損傷の所見であり，不完全主気管支断 裂損傷では認めなかった。

\section{3 . 気管支鏡検査}

TBDI の気管支鏡検查は, 部位診断と重症度診断に 欠かせない。しかし気管支鏡検查の問題点は次の三つ である。

1。気管支鏡施行時は十分な気道内麻酔が必須である。 
咳嗽反射は，気管支損傷部の拡大を助長し，損傷 部からの出血を健常側気管支へ垂れ込ませ，低酸 素血症に陥らせる。

2. 小範囲の気管・気管支損傷病変は凝血で覆われ たり，気管支の粘膜の浮腫や発赤のみしか認識で きず，実際に存在する気管支損傷が見逃される懸 念がある10,13).

3.気管支鏡による気管支損傷の重症度診断は，手 術所見よりも過小評価されやすい.

従って，われわれは上記の (1) 臨床症状, (2) 胸部単 純X線写真所見，(3) 気管支鏡検查所見の 3 つにより, 気管・気管支断裂損傷を診断している.

以上の考察を踏まえ，現在われわれが行っている TBDI の治療方針について述べる。

1. 可能であれば自発呼吸下に手術に移行する，陽 圧換気は TBDI の損傷部を拡大させ, 人工換気か らの空気が縦隔へ流出し, 緊張性緃隔気腫から心 停止を来す恐れがある ${ }^{1)}$. 全層気管支損傷で, 気道 内出血が少なく, 呼吸状態が安定していれば，手 術開始までは自発呼吸で維持する。

2. 換気が保てない症例や人工換気が不可欠の病態 の時，ならびに手術中の気道確保の手法は，損傷 部位により異なる．胸部気管と気管分岐部損傷は, 損傷部を越え片肺挿管する ${ }^{11}$ 。気管分岐部より 2 $\mathrm{cm}$ 以上離れた気管支損傷は, Univent を用いた 受傷側選択的気管支閉塞を行い，片肺人工換気を 行う 7,9$)$

3. 完全断裂損傷あるいはそれに近い状態（日本外 傷学会，気管，気管支損傷分類 IIb，III）であれ ば，可及的速やかに開胸手術を行う．気管・気管 支内膜損傷（気管，気管支損傷分類 Ia）は，経過 観察とする．全層裂傷 (気管，気管支損傷分類 Ib) は，手術を行なわないと裂傷部の肉芽形成から気 管支狭窄をきたし，治療に難渋することが報告さ れている1)。それ由，われわれは，全層裂傷で人工 換気を必要としない場合，先に他臓器損傷の診断 と初期治療を施し，受傷後24時間以内に手術を行 う。

4. 気管・気管支断裂損傷のみの時は，速やかに開 胸し, 気管・気管支単純縫合閉鎖を試みる。一方, TBDI に肺動静脈損傷や深在性肺損傷を合併した 時は，生命が一刻も争われる事態であるから，直
ちに開胸する。最初に大動脈鉗子で肺門遮断を行 い，肺からの出血の制御と肺静脈から吸い込まれ る空気塞栓を防止する。続いて肺葉切除あるいは 肺摘除を選択する ${ }^{11)}$.

\section{結 語}

気管・気管支断裂損傷の診断は，来院時の臨床所見， 胸部単純X線写真所見，気管支鏡所見の 3 つが重要で ある.TBDI の胸部単純写真は，進行性の気管・主気管 支周囲の透亮像, continuous diaphragm sign, Naclerio's V-sign と呼ばれる縦隔気腫像である。さらに気 管・気管支損傷部位に一致した気管支陰影の途絶や不 鮮明化と，損傷部周囲の血腫像が重要である．気管支 鏡検査は TBDI の診断に不可欠であるが損傷程度を 過小評価しやすい.日本外傷学会，気管，気管支損傷 分類 Ib，II，III と診断した時は，速やかに開胸手術を 開始し，気管・気管支単純縫合閉鎖に主眼を置いた手 術を行う。

\section{文献}

1) Devitt JH, Boulanger $\mathrm{BR}$ : Lower airway injuries and anaesthesia. Can J Anaesth 43: 148-159, 1996.

2) Bertelsen $S$, Howitz $P$ : Injuries of the trachea and bronchi. Thorax 27 : 188-194, 1972.

3) Lee RB: Traumatic injury of the cervicothoracic trachea and major bronchi. Chest Surg Clin Nor Am $7: 285-304.1997$.

4) Levin B : The continuous diaphragm sign. Clin Radiol $24: 337-338,1973$.

5) Naclerio EA : The "V sign" in the diagnosis of spontaneous rupture of esophagus. Am J Surg 93: 291-298, 1957.

6）日本外傷学会胸郭・肺損傷分類委員会：日本外傷学会胸 郭・肺損傷分類. 日外傷会誌 $11: 37-42 ， 1997$.

7) Inoue $\mathrm{H}$, Shohtsu $\mathrm{A}$, Ogawa J, et al: Endotracheal tube with movable blocker to prevent aspiration of intratracheal bleeding. Ann Thorac Surg 37 : 497-499, 1984.

8) Kirsh MM, Orringer MB, Behrendt DM, et al: Management of tracheobronchial disruption secondary to nonpenetrating trauma. Ann Thorac Surg 22 : 93-101, 1976.

9) Inoue $H$, Suzuki I, Iwasaki $M$, et al : Selective exclusion of the injured lung. J Trauma 34 : 496-498, 1993.

10) Iwasaki $M$, Kaga $K$, Inoue $H$, et al: Bronchoscopy findings and early treatment of patients with blunt tracheo-bronchial trauma. J Cardiovasc Surg $35: 269$ $-271,1994$ 
11) Nishiumi N, Maitani F, Tsurumi T, et al : Blunt chest trauma with deep pulmonary laceration. Ann Thorac Surg 71 : 314-318, 2001.

12) Calhoon JH, Grover FL, Trinkle JK: Chest trauma. Thoracic surgical consideration for the pulmonologist. 13 : 55-67, 1992.
13) Wan YL, Tsai KT, Yeow KM, et al: CT findings of bronchial transection. Am J Emerg Med 15 : 176-177, 1997.

\title{
Diagnosis of right main bronchus disruption injury facilitated by chest roentgenography findings : case report
}

\author{
Noboru Nishiumi, Sakashi Fujimori, Atsushi Hamamoto, Fumio Maitani \\ Kichizo Kaga, Masayuki Iwasaki, Hiroshi Inoue
}

Division of General Thoracic Surgery, Department of Surgery, Tokai University School of Medicine

The incidence of tracheobronchial disruption injury in cases of blunt chest trauma is low, but the associated mortality rate is high. However, accurate pathologic assessment using appropriate diagnostic imaging and early treatment may be useful in reducing the mortality rate in patients with this injury. We report here the case of the eighteen-year-old male of a motorcycle accident patient for whom chest roentgenogram on admission aided the diagnosis of injury of the right main bronchus (Japanese Association for the Surgery of Trauma in Japan, Tracheobronchial Injury Classification Ib). Tracheobronchial stripe, emphysema shadows around the trachea and the right main bronchus, the continuous diaphragm sign, and right Naclerio's V-sign were observed on the chest roentgenography, suggesting mediastinal emphysema. In addition, the shadow of the right main bronchus near the azygos vein was blurred, and a shadow indicative of hematoma was observed around the lateral azygos vein. Based on these two findings in particular we made a diagnosis of disruption injury of the right main bronchus. The injured site was closed by direct suture repair and postoperatively the patient's condition is good. 